\title{
GEOMEDIA ROLE FOR MOUNTAIN ROUTES DEVELOPMENT. MESEHE AND PISOIU WATERFALL COMPARATIVE STUDY
}

\author{
Ni Made ERNAWATI ${ }^{1}$, Adrian TORPAN ${ }^{2}$, Mihai VODA ${ }^{3}$
}

DOI: 10.21163/GT_2018.131.05

\begin{abstract}
:
This study discusses a tropical and a temperate forest route development to Mesehe and Pisoiu Waterfall supporting sustainable tourism development in Pohsanten Community, Bali, Indonesia and Bistra, Romania. It is a qualitative study using a combination of observation, direct participation and non- structured interviews as data collecting methods. Geo-data was collected during forest expeditions, interactions and interviews with local community members who participate in tourism. Re-establishing the geo-heritage supports sustainability to the people in terms of socio economic wellbeing, promotes legal use of forest and conservation. The study suggests 3 types of products: Village off road vehicle (ORV) recreation, mountain biking, and forest trekking. It concludes tourism could be a solution to the misuse of natural environment, brings about socio cultural and economic benefits to the members of the village; thus, sustainable tourism development for Pohsanten and Bistra communities.
\end{abstract}

Key-words: geomedia, ORV, community-based tourism, geo-tagging, recreation.

\section{INTRODUCTION}

Technology evolution is reflected in every aspect of people's life, challenging continuous learning and fast adaptation. Considering humans as the central component of surrounding Geosystem, the use of geographical techniques for location referencing progressed from paper maps to mobile phones map applications (Voda, 2013). How to place a specific location in space represented a question that has generated a range of different specialized responses. Coordinates calculation, correct position determination constitute the privilege of geospatial tools manipulators (Luo et al., 2009).

Direct on field measurements transition to satellite imagery interpretation, GIS advancements to open source maps enabled geographical creativity and unexpected visualization opportunities of world local environments. Web-based GIS and interactive digital cartography are representing the new geospatial technologies in the location-aware future (Wilson, 2012; 2014). The visualization of diverse digital geo-information coming from different media sources represents Geomedia (Voda, 2015; Digital Earth, 2014). Geographical location related details are provided by Geomedia tools like Google Maps, Google Earth, Facebook, Flickr, Instagram, online and offline maps or navigation geoapplications developed for mobile phones (Jin et al., 2010; Google Earth, 2017).

Wilson (2014) observed the increasing diversity of interfaces that are using geospatial data, underlining the importance of GIScience in the process of communities' culture comprehension. The worldwide availability of smartphone devices has opened new opportunities for the future use of geospatial technologies.

\footnotetext{
${ }^{1}$ Politeknik Negeri Bali University, Jimabaran, Bali, Indonesia, madeernawati@pnb.ac.id;

${ }^{2}$ Folkuniversitetet, Jönköping, Sweden, adriantorpan@yahoo.com;

${ }^{3}$ Dimitrie Cantemir University, 540545, Targu Mures, Romania, mihaivoda@cantemir.ro;
} 
Luo et al. (2010) analyzed important modalities of geo-information useful in multimedia and vision research stating that geo-tagging has contributed to communities' geo-awareness. Their research shows how digital photography geo-tagging reveals place and position information, adding geographical recognition metadata to a variety of images, videos or photos taken with GPS incorporated devices.

Geo-information in multimedia could assist in developing tourism attractions particularly: trekking, Off Road Vehicle (ORV) recreation, mountain biking, mountain climbing. As the information technology could provide hand on information needed by geotourists, while in the middle of wilderness, it is worth examining its impact on local communities which already are beneficiaries of mobile devices and internet access. Smartphones can provide directions based on geo-tagged photos, indications on the surrounding human or natural environments, cultural resources and various sharing opportunities for information distribution or validation by other online world wide travellers.

Various investigations have explored the subject, especially Schwanen and Kwan (2008), Wang et al. (2012), Dickinson et al. (2014), Meng et al. (2014), Martínez-Graña et al. (2017), Sidali et al. (2017), showing that modern geomedia, particularly smartphones applications are offering information, protecting and promoting the local natural and cultural potential. Geomedia enables the visualizing process of a diversity of places geographical realities in a different way. The best example is Airbnb platform, which has a powerful impact on travellers' decisiveness to select destinations, based on locations accurate maps, directions, photos, reviews and rating system (Voda \& Negru, 2015).

Inal et al. (2017) presented the technological evolution of the smartphones in archaeological applications, in the acquiring process of the coordinates system with mobile phones instead of GPS devices, outlining the visual representation importance of the results on Google Earth Program. Baiocchi et al. (2017), stated that the single point positioning receivers advance was represented by the new Global Navigation Satellite Systems (GNSS) techniques introduced for Samsung Galaxy III and recent IPhone models. A legend could build a strong brand for tourist destinations (Robinson \& Wiltshier, 2011; Ernawati, 2015). In Transylvania- Romania, for example, the legend of Dracula may become the main tourism attraction with the support of Geomedia tools. This kind of legends, connected to local angels, also exists in Bali, Indonesia (Ernawati, 2015).

This article intends to discuss the use of Geomedia tools in the establishment process of sustainable tourism activities that could bring benefits to the local Transylvanian and Balinese communities, as well as present off road vehicle, mountain-biking and trekking options along the Pisoiu and Mesehe waterfall routes. The results of the study could be used as a reference to assist communities in developing tourism in the analyzed villages of Pohsanten and Bistra that could provide social and economic benefits, promote conservation, and prevent the misuse of the mountain wild areas as described by Voda, Torpan \& Moldovan (2017), Voda, Moldovan, Torpan \& Henning (2014).

\section{RESEARCH METHODOLOGY}

This is a qualitative study using observation, direct participation and non-structured interviews as data collecting methods. Data was collected during the forest trekking, interactions with locals who participate in tourism, and interviews that were conducted with the head of farmer organization, local guides and other tourism related service providers in the village. 
Google Earth and Google Maps ${ }^{\mathrm{TM}}$ datasets of Transylvania and Bali were used for maps elaboration. Mountain routes were firstly explored for GPS tracking by ORV, motorbike and pedestrian means. The tracks were charted on orthophoto maps and topographic profile graphs were created in ArcGIS 10 using digital elevation models and Interpolation Line from 3D Analyst toolbar (Google Earth, 2017; ArcGIS Server, 2017).

Smartphones technology was used for the geotagging process of images taken along the identified routes, recording the compas direction of Iphone8+ incorporated camera and automatically embedding GPS location. Location data and comprehensive metadata were procured from GPS trajectories identifying the exact longer stops positions where photos were taken. Invert geo-coding was executed to get or provide a semantic connotation of the places correlated to the GPS coordinates. The method was expanded to envisage the semantic position typology based on site geographical observations (Liu et al., 2006).

Considerable Android applications were tested for coordinate's identification and mapping purposes but location accuracy of GSM providers is approximately 3 and a half meters. Inal et al. (2017), observed that this precision is sufficient for Archaeological sites.

The Pic2Map exchangeable image file (EXIF) data viewer methodology was used for location determination based on analysis of iPhone8 and Xiaomi Redmi 3S image data. The photo coordinates were extracted from the interchange information digital files and located on Google Maps ${ }^{\mathrm{TM}}$ (Pic2Map, 2018).

\section{MESEHE AND PISOIU MOUNTAIN ROUTES}

Mesehe Waterfall is located near Pohsanten village $120 \mathrm{~km}$ from Jimbaran. The exit point from Bali main road Denpasar - Gilimanuk is located at the Obelisk monument Tugu. The Pasatan temple is about $10 \mathrm{~km}$ distance from the exit point that could be easily reached by ORV or motorcycle.

Pisoiu Waterfall is placed upstream Cofu Valley, located in Calimani Mountains with Bistra village as the mountain route entry point at $66 \mathrm{~km}$ from Targu Mures. Motor-bike and ORV constitute reasonable options to reach the waterfall. Both tracks are running through the villagers households as the routes are going deeper into the natural scenery that becomes more picturesque as entering the forests. Airbnb platform offers genuine local accommodation options in both analyzed locations. Motor bike, mountain bike and ORV tours around scenic Pasatan area using the temple outer section as a break point could represent moderate options before accessing the tropical forest trail in Bali. In Transylvania, the mountain gravel road that stretches from Bistra village to Donca, Mijlocu and Stegii valley is often used for motorbike, mountain bike and ORV recreational activities.

Pasatan temple is the center of spirituality in Pohsanten village; moreover, the temple is not only worshiped by Pohsanten community members but also by Balinese community. Many people feel having a close connection and being blessed by the Water Goddess abodes the temple. The nearby Subak (s) which are the traditional farming organizations pray in Pasatan temple for a successful planting season; as practiced by the Subak of rice farming organization praying in Bedugul temple (Norken, Suputra \& Arsana, 2017). A legend told that the temple is spiritually related to the Mesehe waterfall located in the mountain at the upper edge of the area. The waterfall is said to be an angel bathing and a purification place for the Goddess before resides in the temple. In the old-time people in the village conducted a pilgrimage: Pasatan temple to Mesehe angel-bath waterfall, nowadays the practice ceased and even the track across a tropical forest to the waterfall has lost. 
Currently the villagers want to re-establish the practice and combine it with tourism activities. The Goddess legend could become a theme for Pohsanten tourism as argued by House (1997). In order to be successful, a mountain rural area needs to have geomedia representation based a strong distinctive tourist attractions theme. The difficult trail from Pasatan temple to Mesehe Angel-bath Waterfall stretches through a tropical forest consisting of $4.4 \mathrm{~km}$ pathways which takes about 4 hours trekking. This whole route is for well trained, adventure trekkers (Fig. 1).

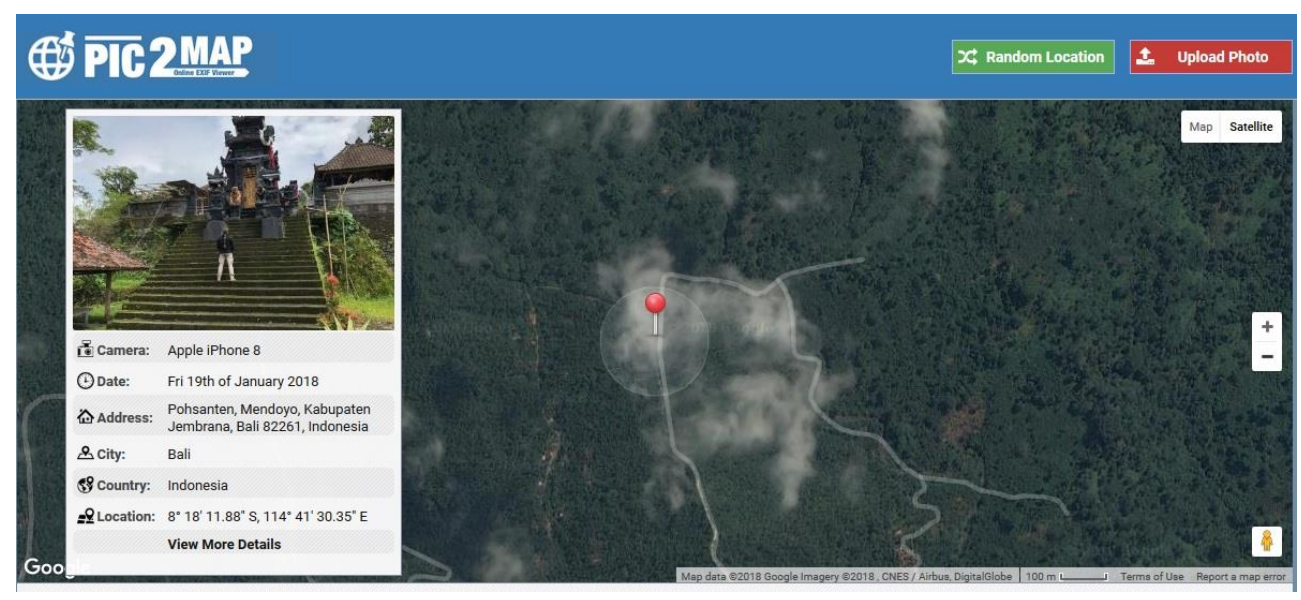

Fig. 1. Pasatan Temple study area in Bali, Indonesia.

There are few posts along the route wherein each has its own highlight of activities and point of interest. Semantic connotation of the stopping places (Stony River crossing) were correlated to the GPS coordinates. (Fig. 2). Pasatan Temple is the starting point, which is the spiritual center where in Dewi Danu the Lake Goddess is worshipped. Archeological artifacts were found in Pasatan temple area and categorized based on Android GeoApp photo identification process (Inal et al., 2017). There is a central stone with 7 orbiting rocky artifacts with different carved symbols. For the Pohsanten village people, apart from praying place the temple constitutes a meditation quarter.
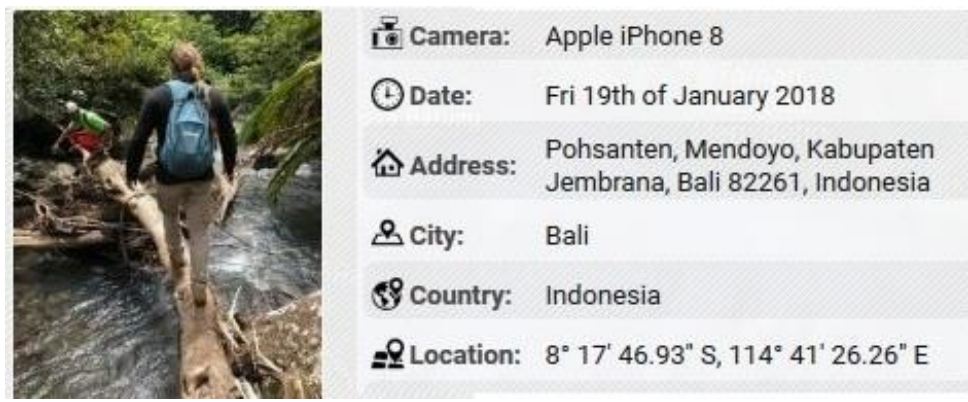

Fig. 2. Geo-tagged Iphone8 photo from Stony River crossing. 
Stony River crossing represents the place where tourist could rest and have clear water. This post can be the first terminating point for the trekkers (Magyari-Saska \& Dombay, 2016). Location determination was done based on the analysis of iPhone 8 image data interpretation and incorporated GPS sensor. Proposed tourist activities in the area can include river-bathing, fishing or river canyoning along its clear water-flow. The distance is $1 \mathrm{~km}$ from Pasatan Temple forest entrance.

The tropical forest resting point placement was decided during the common expedition organized with Pohsanten representants, being located half way from the temple to the waterfall (Fig. 3). Reaching this Banyan tree (Ficus Benghalensis) location requires more physical effort, being considered a challenging section because of the steep mountain climb. This was an eco-spot where various old grow forest trees were identified and described for the Pohsanten Geomedia platform. It is the viewing point from the mountain top and the last resting area before reaching the Mesehe waterfall.

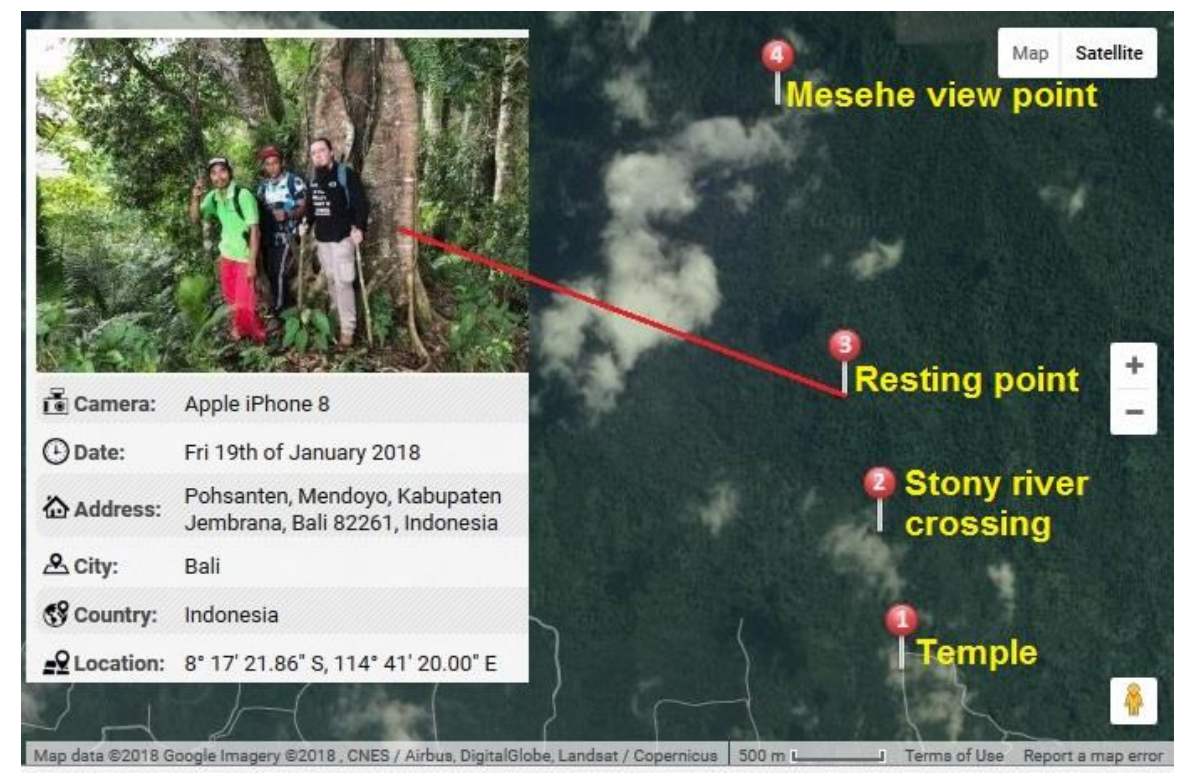

Fig. 3. Pic2MAP photo location determination on Mesehe route (Pic2Map, 2018).

The terminating point of the Mesehe forest trail is the waterfall, which has two platforms. The first platform host the viewing and the resting area and the second represents a sacred space with restricted access unless for praying purposes. Mesehe Waterfall suggested route options development for tourist activities could include Pohsanten Village motor bike tours, recreational trekking using the Stony River as a terminating point, and the Mesehe Waterfall tropical forest adventure for professionals. Pisoiu Waterfall from Cofu Valley is located in Caliman Mountains along a temperate zone forest exploitation route that follows Bistra River and Cofu tributary. Transylvanian mountain routes were explored for GPS tracking by ORV (Suzuki Grand Vitara 4x4) and motorbike (DRZ 400E).

The importance of local legends as House (1997) argued can be valorized on Geomedia platform for Bistra Village. Compared to Pohsanten Goddess legend from Bali, the Dracula myth has better international visibility but no geospatial coordinates. 


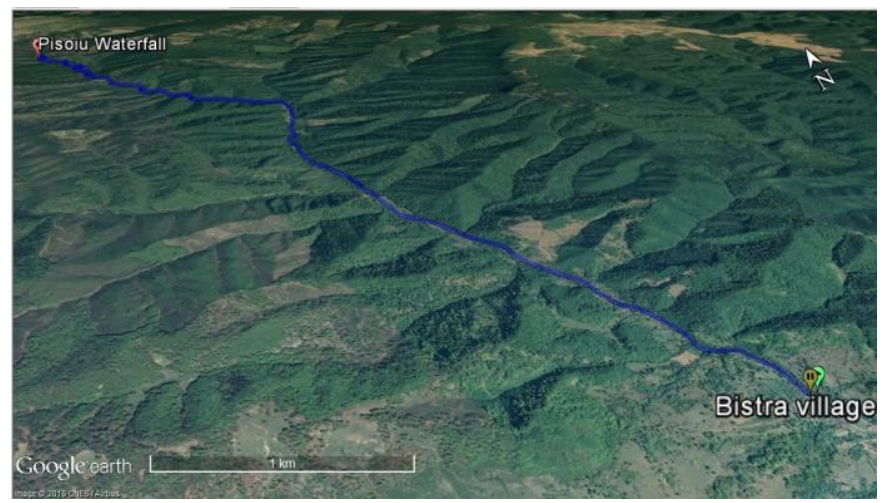

Fig. 4. Pisoiu Waterfall route to Dracula Castle in Transylvania.

As Bram Stoker described the black horses-drawn carriage journey through the Transylvanian Mountains in his Dracula book, our research identified the geographical locations of Jonathan Harker's passage on the Dracula Castle way (Stoker, 1897, Negru et al., 2015). Our studies are indicating the Iszten Szek mountain top as the Caliman Range entrance reference related to Dracula Castle access. In order to clarify the Borgo Pass contradiction, the mountain range crossing options were determined, taking into account the Iszten Szek peak restricted visibility from the South direction. Further research has demonstrated that Bistra River with the right hand tributary Cofu constitutes the first passage alternative to Colibita Lake and Borgo Pass, where Dracula Castle was built (Fig. 4). Caliman range gravel roads topographic profile graphs were created for mountain gravel roads, using collected informations and Google Earth datasets. The most spectacular route is represented by Luca Bradului Village- Negoiu Saddle- Toplita Monument gravel road, which can easily cross the $2000 \mathrm{~m}$ altitude volcanic mountains to reach the legendary Dracula Castle (Fig. 5).

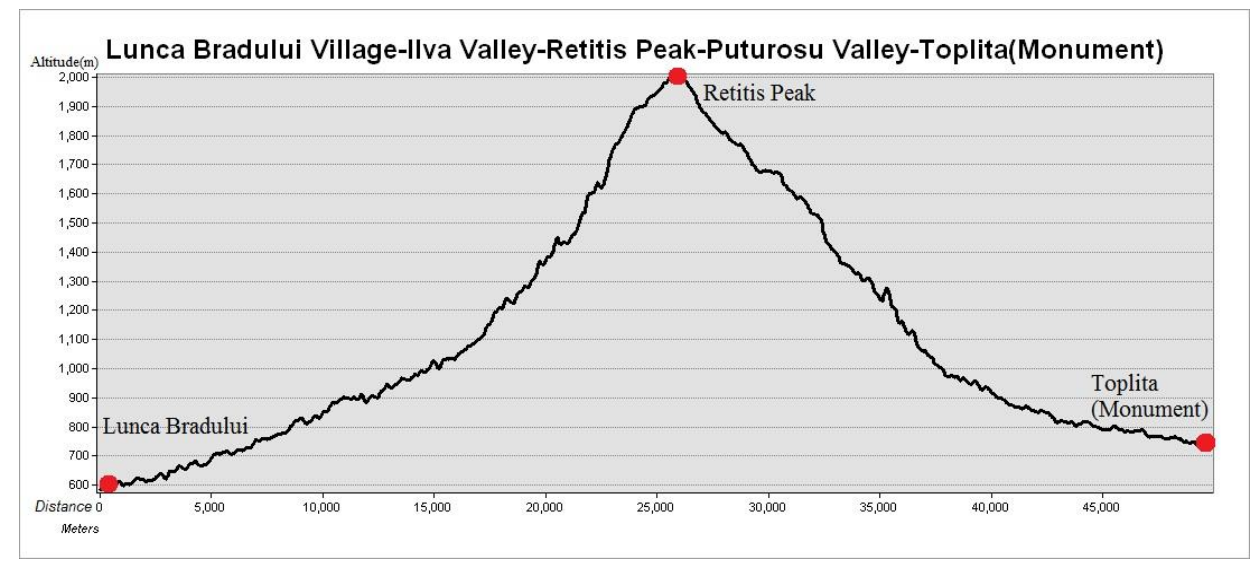

Fig. 5. Caliman range gravel route profile graph 
Google Maps ${ }^{\mathrm{TM}}$ datasets of Transylvania and Bali were used for Geomedia platforms elaboration. The geotagging process of photos taken along the identified routes was initiated based on available smartphones technology of iPhone8 and Redmi $3 \mathrm{~S}$ Xiaomi digital cameras.

Our research is recommending three recreational activities for potential tourists, based on local community's decision makers' interviews: gravel roads ORV tours, mountain biking, and forest adventure trekking. Semantic nomination of the resting locations, significant crossing spots and terminal points were done using smartphones GeoApps correlated to the GPS provided directions. Redmi 3S Xiaomi Android software technology proved to be more accurate than iPhone 8 Apple (Fig. 6).

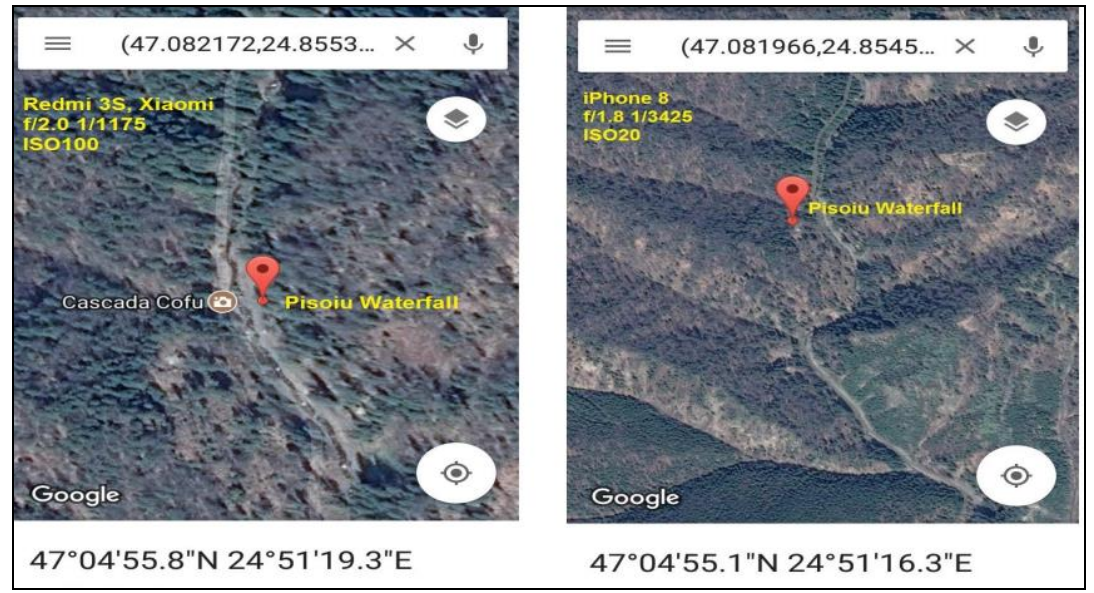

Fig. 6. Pisoiu Waterfall comparative geo-location. Redmi 3S Xiaomi vs iPhone8.

Geo-tagged media represented by specific community members photos (from Bali or Transylvania) or blogger sites (local or international) are offering particular details for numerous location-based utilities such as Airbnb local homes near Pohsanten in Bali, Indonesia or Bistra in Transylvania, Romania (Fig. 7). Tourist can choose what to visit based on social media images, travel blogs or Airbnb type platforms (Luo et al., 2010; Voda \& Negru, 2015).

Mesehe and Pisoiu Waterfall mountainous routes are both connected to protected areas, being situated in the vicinity of West Bali National Park and Calimani National Park. The access roads are located in rural communities of Pohsanten, Bali and Bistra, Transylvania with poor inhabitants but various cultural resources that can be valorized using the new Geomedia technological advances. Our research integrated field photography and online mapping techniques encouraging locals to share their geo-tagged photos for the project scientific database (USGS, 2017). Smartphones diverse applications with geotagged photos and social media sharing options, mobile networks wider coverage and continuously growing internet availability are transforming people's life. Remote villages are offering exquisite rural home stays and the villagers become real experiences providers on Airbnb. The use of Geomedia tools can directly influence the economic development of Pohsanten and Bistra specific chosen regions, providing instant online access to Facebook, Instagram or Airbnb. 

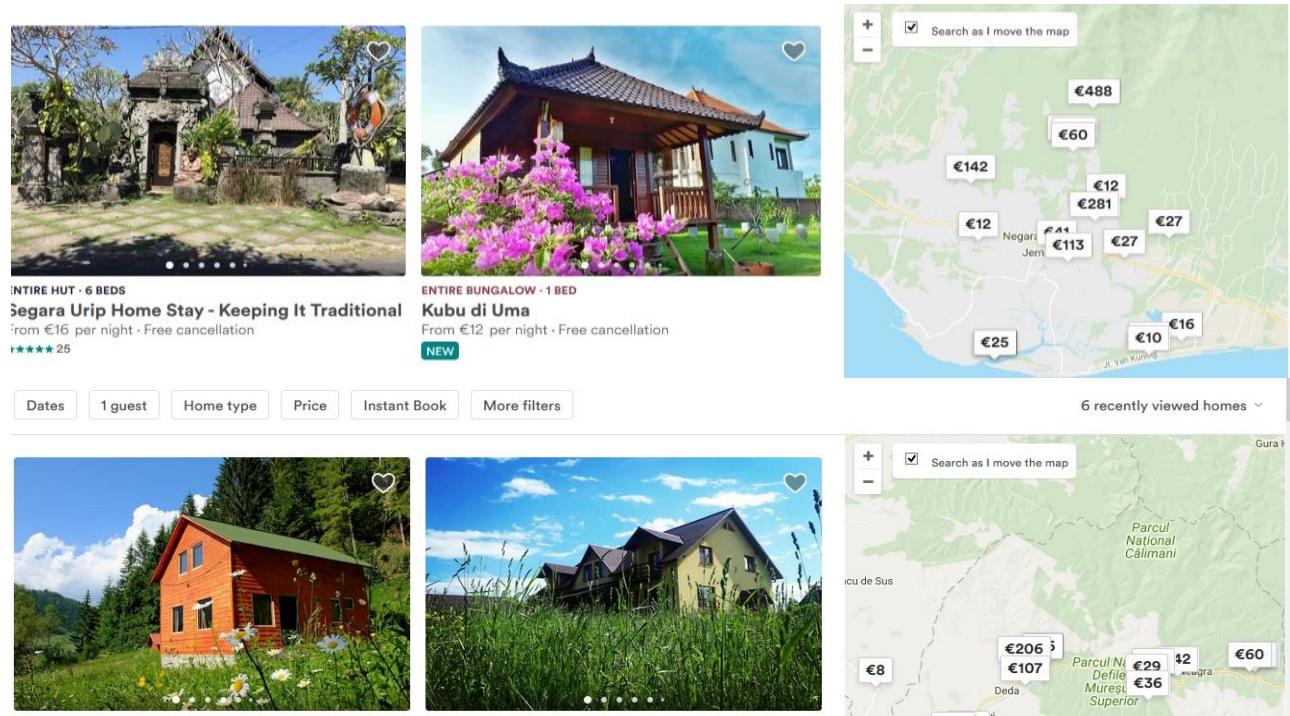

ENTIRE CABIN +8 BEDS

Cozy Mountain Cabin in Stanceni

From $€ 60$ per night
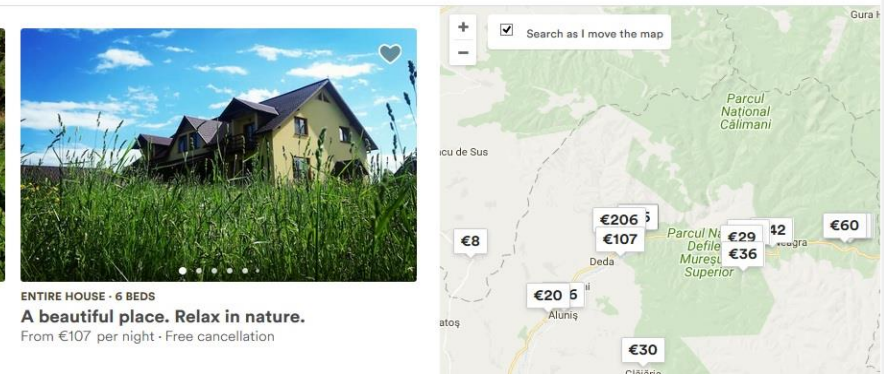

Fig. 7. Local homes accommodation offers near Pohsanten, Bali (up) and Bistra (bottom), Transylvania (Airbnb, 2018).

The sharing of Bali or Transylvania idle attractions via tech platforms can generate economic benefits. Sharing economy is helping the villagers to earn extra income and boost their community (Rinne, 2018).

\section{DISCUSSION}

Sustainable tourism involves and assesses three elements: economic, socio-cultural and natural environment (UNWTO, 2013). Village tourism or community-based tourism (CBT) represents a form of sustainable tourism called alternative tourism at its earlier stage. Eadington and Smith (1992) argue that alternative tourism attempts to develop a more meaningful 'host and guest' relationship, and is more sensitive to local people and the environment (Loker-Murphy \& Pearce, 1995), based on community values and environmental ethics (House, 1997). Weaver (2006) argues the characteristics of alternative tourism include: catering for special interest tourists; using pre-existing attraction of authentic culture, history, and natural environment; tourist and local orientation; small-scale and local community ownership businesses; observing the principles of dispersed pattern and low density; unobtrusive and vernacular style architecture features; economic features include low tourist receipts, linkage with local sectors, low leakage, high multiplier effect, and the role of tourism is a supplementary economic activity; regulation features comprise high local community control, public intervention, priority of public wellbeing, and a longterm time frame. Community-based tourism could be defined as a form of tourism development that prioritizes community participation during planning and operation while delivering quality tourist experiences; utilizes culture and natural environment as tourist attractions and is oriented to their conservation and for the prosperity and wellbeing of the 
locals. Academics discuss the positive impacts of CBT, e.g. it supports cultural conservation (Picard, 2008); brings about positive economic benefits and is used as a catalyst for community development (Singh, 2012; Butcher, 1997). Apart from the benefits, some unfavorable impacts also envisioned, Beeton (2006) and Butcher (1997) summaries the possible negative impacts of tourism as natural environment destruction, economic dislocation and cultural degradation.

The World Tourism Organisation (WTO) defines sustainable tourism as '... meeting the needs of present tourists and host regions while protecting and enhancing opportunities for the future' (WTO, 1998, p. 21). Sustainable tourism is 'envisaged as leading to the management of all resources in such a way that economic, social and aesthetic needs can be fulfilled while maintaining cultural integrity, essential ecological processes, biological diversity and life support systems' (Lu \& Nepal, 2009, p. 6).

Further research is needed for the re-establishing of the traditional pilgrimage from Pasatan temple to the Mesehe Waterfall and for Dracula legend search from Bistra Village to the Pisoiu Waterfall. Tourism development will support sustainability to the Bali and Transylvania villagers in terms of socio economic wellbeing, promotes legal use of forest and conservation. This also provides a legal admission from the local government for the village people to pass through the forest to reach the waterfall legally. Activities in the forest will be exposed and monitored through sustainable tourism practice; thus, reduce illegal and detrimental forest activities. For the development and operation of tourism in Pohsanten and Bistra communities, is vital to permanently observe the principles of sustainable tourism and CBT. Pohsanten Village is a farming area where cacao is the main produce and Bistra area is mainly orientated on foresting activities. Mountain routes tourism development is expected to provide an additional source of income for the local inhabitants, to influence the local socio-culture in a positive way, to increase people's awareness and to promote forest conservation actions (Voda, Torpan \& Moldovan, 2017).

\section{CONCLUSIONS}

The use of Geomedia to valorize mountain resources using specific geosites as the highlight and designated routes for connection, contributes to the practice of sustainable living particularly sustainable tourism in villages situated in mountainous regions. The results would be applicable to all mountain communities because Geomedia tools are free to use and widely available. The positive Geomedia impacts could be in a form of: provision of an alternative source of income; broaden the horizon and the perspective of the village people; the conservation of the natural environment particularly the forest, which in turn promotes a better function of natural cycles, maintaining a dynamic equilibrium of existing ecosystems. Geomedia also provides an opportunity for visitors to know more about nature and forest, whilst enjoy quality natural tourism experiences.

Pohsanten community determined the Indonesian Directorate of Higher Education to fund preparation activities for community based tourism development: human resources buildout, brochures and website creation, sing boards along the Mesehe Route forest trail with information panels about natural habitats and ecosystems. But the obtained grant scheme is significantly smaller than expected and there are many challenges: the outer quarter of the temple needs to be considered representable as a visitor reception area. Paving the track up to the River crossing is recommended, restrooms, guests' rooms and restaurant facilities attached to the temple vicinity are envisioned. The Pohsanten village has public land where these facilities could be built. The village authorities at all level from 
Bali, formal and traditional leaders, the community members and a considerable number of farmers are enthusiast about developing tourism perspective. Online available GeoApps for travellers' smartphones with incorporated GPS sensor will contribute to the mountain routes accuracy maintenance and minimum impact on natural ecosystems. Mobile phone geo-applications will provide necessary details about the surrounding habitats which are following the forest trails with photos for different species, resting areas and available accommodation options in the mountain proximity. Community members will be encouraged to present their households and favourite activities as experiences, based on Airbnb homes and experiences models developed for the new generation of sharing economy tourists.

\section{R E F E R E N C E S}

Airbnb, (2018). Airbnb platform [Online]. Available from: http://www.airbnb.com, [Jan. 2018].

ArcGIS Server, (2017). Website of ArcGIS Server [Online]. Environmental Systems Research Institute, Available from: www.esri.com/software/arcgis/arcgisserver/, [Accessed Dec. 2017].

Baiocchi, V., Constantino, D. \& Vatore, F. (2017). Suitability of Averaging GPS/GNSS Paths to Build Geometrically Correct Digital Road. Geographia Technica, 12 (2), 1-9.

Beeton, S. (2006). Community development through tourism. Collingwood, Australia: Landlinks Press.

Butcher, J. (1997). Sustainable development or development?. In M. J. Stabler (Ed.), Tourism \& sustainability principles to practice (pp. 27-38). Oxon, UK: Biddles ltd.

Dickinson, J.E., Ghali, K., Cherrett, T., Speed, C., Davies, N., Norgate, S. (2014). Tourism and the smartphone app: capabilities, emerging practice and scope in the travel domain. Current Issues in Tourism. 17(1), 84-101.

Eadington, W. R., \& Smith, V. L. (1992). Introduction: The emergence of alternative form of tourism. In V. L. Smith \& W. R. Eadington (Eds.), Tourism alternatives: Potential and problem in the development of tourism (pp.1-12). Phyladelphia, US: University of Pennsylvania Press.

Ernawati, N. M. (2015). Producer-market orientation of community-based tourism (CBT) products: A case study in Bali, Indonesia. Unpublished thesis. Perth: Edith Cowan University.

Google Earth (2017) Google Earth Image. [Online] Available from www.google.com/earth/ [Accessed December 2017].

House, J. (1997). Redefining sustainability: A structural approach to sustainable tourism. In M. J. Stabler (Ed.), Tourism \& sustainability principle to practice (pp. 89-104). Oxon, UK: Biddles ltd.

Inal, C., Kocak, O., Esen, O., Bulbul, S. \& Kizgut, R. (2017). Surveying and Mapping using Mobile Phone in Archaeological Settlements. Geographia Technica, 12 (2), 82-96.

Jin X., Gallagher A., Cao L., Luo J. \& Han J. (2010) The wisdom of social multimedia: using Flickr for prediction and forecast. In Proceedings of ACM Multimedia.

Liu L., Wolfson O. \& Yin H. (2006) Extracting semantic location from outdoor positioning systems. In Proceedings of the IEEE International Conference on Mobile Data Management.

Locker-Murphy, L. \& Pearce, P. (1995). Young budget travellers: Backpackers in Australia. Annals of Tourism Research, 22(4), 819-843.

Lu, J., \& Nepal, S. K. (2009). Sustainable tourism research: An analysis of papers published in the Journal of Sustainable Tourism. Journal of Sustainable Tourism, 17(1), 5-16. doi:10.108/09669580802582480.

Luo Z, Li H, Tang J, Hong R, \& Chua T-S (2009) ViewFocus: explore places of interests on Google maps using photos with view direction filtering. In Proceedings of ACM Multimedia.

Magyari-Saska Z., \& Dombay I. (2016). Mixed Group Hikers optimal resting place location along trails. Test Area at Lacu-Rosu Region (Romania). Geographia Technica, 11 (2), 69-77.

Martínez-Graña, A.M., Serrano, L., González-Delgado, J. A., Dabrio, C. J. \& Legoinha, P. (2017) Sustainable geotourism using digital technologies along a rural georoute in Monsagro (Salamanca, Spain), Int.J.Dig.Earth, 10:2, 121-138, DOI: 10.1080/17538947.2016.1209582. 
Meng, B., Min-Hyung, K. \& Yeong-Hyeon, H. (2014). Users and Non-users of Smartphones for Travel: Differences in Factors Influencing the Adoption Decision, A.Pac.Jour.Tour.Res., DOI: 10.1080/10941665.2014.958508.

Negru, R., Voda, M. \& Dumitrache, N.D. (2015). Geodiversity assessment as a tool for Geotourism in the Istenszeke Natural Park. Academica Science Journal, Geographica Series, 1(6), 13-21.

Norken, I N., Suputra, I K. \& Arsana, I G. N. K. 2017. Institutional and Regulatory Roles in Maintaining Sustainability of Subak as a World Cultural Heritage in Bali. Asian Agri-History, 21(4), pp. 245-254

Picard, M. (2008). Balinese identity as tourist attraction from 'cultural tourism' (pariwisata budaya) to 'Bali erect' (ajeg Bali). Tourist Studies, 8(2), 155-173. doi: 10.1177/1468797608099246

Pic2Map (2018) Photo Location Viewer [Online]. Available from: https://www.pic2map.com/ [Accessed January 2018].

Rinne, A. (2018), The dark side of the sharing economy [Online]. Available from: https://www.weforum.org/agenda/2018/01/the-dark-side-of-the-sharing-economy/ [Accessed January 2018].

Robinson, P. \& Wiltshier, P. (2011). Community tourism. In P. Robinson, S. Heitmann, \& P. Dieke (Eds.), Research themes for tourism (pp. 87-99). Wallingford, UK: Cabi. Available from http://www.cabi.org.ezproxy.ecu.edu.au/CABeBooks/ShowPDF.aspx?PAN=20113005506

Schwanen, T. \& Kwan, M-P. (2008). The Internet, Mobile-phone and Space-time Constraints, Geoforum, 39 (3) 1362-1377.

Sidali, K. L., Huber, D., \& Schamel, G. (2017). Long-Term Sustainable Development of Tourism in South Tyrol: An Analysis of Tourists' Perception. Sustainability, 9(10), 1791.

Singh, S. (2012). Community participation - in need of a fresh perspective. In T. V. Singh (Ed.), Aspects of tourism: Critical debates in tourism (pp. 113-117). Bristol, UK: Channel View Publications.

Stoker, B. (1897), Dracula, Westminister Archibald Constable and Company a Whitehall Gardens, London.

UNWTO (2016) United Nations World Tourism Organisation [Online]. Sustainable development of tourism. Available from: http://sdt.unwto.org/en/content/about-us-5 [Accessed September 2016].

USGS (2017) The United States Geological Survey [Online]. Land Cover Trends Geotagged Photography. Available from: https://lta.cr.usgs.gov/lct_photos [Accessed December 2017].

Voda, M., Torpan, A. \& Moldovan, L. (2017). Wild Carpathia Future Development: From Illegal Deforestation to ORV Sustainable Recreation. Sustainability, 9(2254), 1-11.

Voda, M. \& Negru, R. (2015). Geomedia role in Mures Valley Castles Tourism Development between Ogra and Brancovenesti. Academica Science Journal, Geographica Series, 1(6), 63-70.

Voda, M., Moldovan, L. Torpan, A. \& Henning, H. (2014). Using Gis for Mountain Wild Routes Assessment in Order to Qualify Them for Tourism Valorisation. Geographia Technica, 09 (1), 101-108.

Voda, M. (2013). The role of Geospatial Technologies, Geographic Information and ICT in promoting rural communities sustainable development in Transylvania. Academica Science Journal, Geographica Series, 3, 90-95.

Wang, D., Park, S., \& Fesenmaier, D.R. (2012). The Role of Smartphones in Mediating the Tourism Experience. Journ. of Trav. Res., 51(4), 371-387.

Weaver, D. (2006). Sustainable tourism theory and practice. Oxford, UK: Elsevier.

Wilson, M.W. (2012). Location-based services, conspicuous mobility, and the location-aware future. Geoforum 43, 1266-1275.

Wilson, M.W. (2014). Geospatial technologies in the location-aware future. Journal of Transport Geography, 34, 297-299.

World Tourism Organization [WTO]. (1998). Guide for local authorities on developing sustainable tourism. Madrid, Spain: World Tourism Organization. 